\title{
Sistem Pendukung Keputusan Pemberian Bantuan Program Keluarga Harapan (PKH) dengan Metode Elimination Et Choix Traduisant la Realite (ELECTRE) Studi Kasus Kecamatan Borbor
}

\author{
Mukhlis Ramadhan, Dicky Nofriansyah, Firahmi Rizky \\ STMIK Triguna Dharma
}

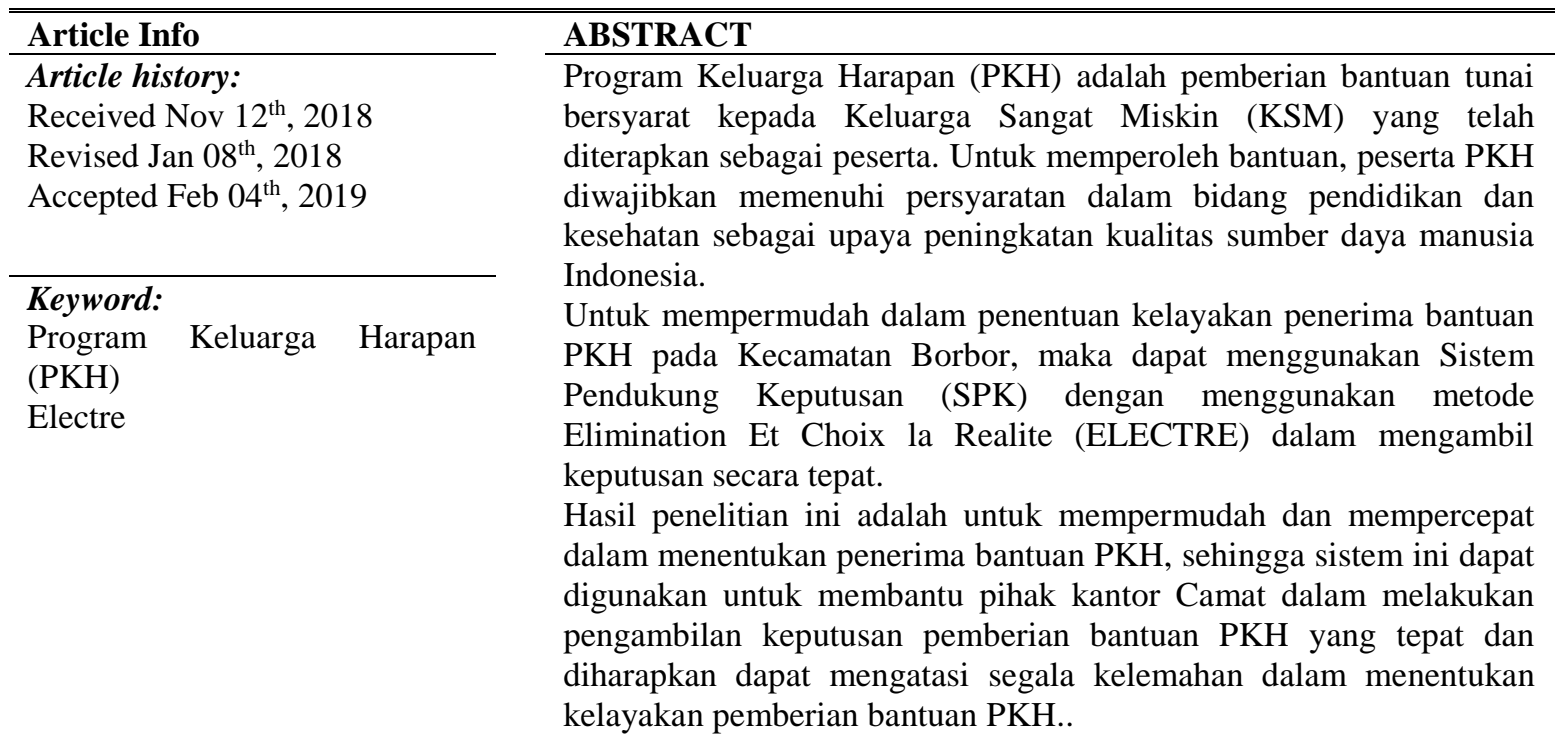

Copyright @ 2019 STMIK Triguna Dharma. All rights reserved.

First Author

Nama: Mukhlis Ramadhan

Kantor : STMIK Triguna Dharma

\section{PENDAHULUAN}

Program Keluarga Harapan (PKH) adalah pemberian bantuan tunai bersyarat kepada Keluarga Sangat Miskin (KSM) yang telah diterapkan sebagai peserta. Untuk memperoleh bantuan, peserta PKH diwajibkan memenuhi persyaratan dalam bidang pendidikan dan kesehatan sebagai upaya peningkatan kualitas sumber daya manusia Indonesia. Dalam jangka pendek, Program ini bertujuan mengurangi beban KSM, sedangkan dalam jangka panjang diharapkan dapat memutus rantai kemiskinan antargenerasi, sehingga generasi berikutnya dapat keluar dari kondisi kemiskinan dan lebih sejahtera.

Selama ini penentuan penerima bantuan PKH masih manual tanpa menghitung nilai-nilai kriteria, sehingga bantuan sering salah sasaran. Dalam penelitian ini akan ditentukan beberapa kriteria dan data keluarga yang telah diperoleh berdasarkan hasil survei dari Kantor Camat Borbor kabupaten Toba Samosir. Data tersebut akan diolah menggunakan sistem pendukung keputusan.

Et Choix Traduisant la Realite merupakan salah satu metode pengambilan keputusan multikriteria berdasarkan pada konsep outranking dengan menggunakan perbandingan berpasangan dari alternatifalternatif berdasarkan setiap kriteria yang sesuai. Masalah yang dibahas dalam penelitian ini yaitu akan dirancang sebuah perangkat lunak berbasis Dekstop Programming yang diharapkan menjadi solusi pemecahan masalah.

Dekstop Programming adalah pemrograman yang dilakukan dengan memanipulasi elemen-elemen visual yang dilakukan pada sebuah Personal Computer (PC) tunggal. Perangkat lunak yang dirancang mengadopsi metode Elimination Et Choix Traduisant la Realite. 


\section{LANDASAN TEORI}

\subsection{Sistem Pendukung Keputusan}

Menurut Alter (dalam Kusrini, 2007: 15)[1] 'Sistem Pendukung keputusan (Decision Support System) merupakan sistem informasi interaktif yang menyediakan informasi, pemodelan, pemanipulasian data. Selain itu digunakan untuk membantu pengambilan keputusan dalam situasi yang semiterstruktur dan situasi yang tidak terstruktur, dimana tak seorang pun tahu secara pasti bagaimana keputusan seharusnya dibuat. Sistem Pendukung Keputusan (Decision Support System) dapat dikatakan sebagai sistem komputer yang mengolah data menjadi informasi untuk mengambil keputusan dari masalah semi-terstruktur yang spesifik. Sistem Pendukung Keputusan atau SPK biasanya dibangun untuk mendukung solusi atau suatu masalah untuk mengevaluasi suatu peluang. Sistem yang seperti ini disebut aplikasi Decision Support System (DSS). Aplikasi DSS digunakan dalam pengambilan keputusan. Aplikasi DSS menggunakan CBIS (Computer Based Information Systems) yang fleksibel, interaktif, dan dapat diadaptasi, yang dikembangkan untuk mendukung solusi atas masalah manajemen spesifik yang tidak terstruktur. Sistem Pendukung Keputusan tidak dimaksudkan untuk mengotomatiskan pengambilan keputusan, tetapi memberikan perangkat interaktif yang memungkinkan pengambil keputusan untuk melakukan berbagai analisis menggunakan model-model yang tersedia.

Aplikasi sistem pendukung keputusan bisa terdiri dari beberapa subsibtem yaitu subsitem manajemen data, subsistem manajemen model, subsistem antarmuka pengguna, dan subsistem manajemen berbasis pengetahuan (Kusrini, 2007:25-26).[1].

\subsection{Metode Elimination Et Choix Traduisant la Realite}

Metode Elimination Et Choix Traduisant la Realite termasuk pada metode analisis pengambilan keputusan miltikriteria yang berasal dari Eropa tahun 1960-an. Electre adalah akronim dari Elimination Et Choix Traduisant la Realite atau dalam bahasa inggris berarti Elimination and Choice Expressing Reality

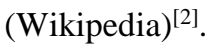

(Jurnal Rekursif, Vol. 3, 2015) ${ }^{[3]}$ ELECTRE merupakan salah satu metode pengambilan keputusan multikriteria berdasarkan pada konsep perangkingan dengan menggunakan perbandingan berpasangan dari alternatif-alternatif berdasarkan setiap kriteria yang sesuai. Metode ELECTRE digunakan pada kondisi dimana alternatif yang kurang sesuai dengan kriteria dieliminasi, dan alternatif yang sesuai dapat dihasilkan. Dengan kata lain, ELECTRE digunakan untuk kasus-kasus dengan banyak alternatif namun hanya sedikit kriteria yang dilibatkan. Suatu alternatif dikatakan mendominasi alternatif yang lainnya jika satu atau lebih kriterianya melebihi (dibandingkan dengan kriteria dari alternatif yang lain) dan sama dengan kriteria lain yang tersisa.

Menurut Akshareari, (2013:22) ${ }^{[4]}$, langkah-langkah yang dilakukan dalam penyelesaian masalah menggunakan metode ELECTRE adalah sebagai berikut :

1. Normalisasi matriks keputusan

Dalam prosedur ini, setiap atribut diubah menjadi nilai yang comparable. Setiap normalisasi dari nilai xij dapat dilakukan dengan rumus.

$\operatorname{Rij}=\frac{x i j}{\sqrt{\sum_{i=1}^{m} X_{i 1}^{2}}}$ untuk $\mathrm{i}=1,2,3 \ldots, \mathrm{m}$, dan $\mathrm{j}=1,2,2 \ldots, \mathrm{n}$

Sehingga didapat matriks $\mathrm{R}$ hasil normalisasi,

$\mathrm{R}=\left[\begin{array}{lll}r_{11} & r_{12} \cdots & r_{1 n} \\ r_{21} & r_{22} \cdots & r_{2 n} \\ r_{m 1} & r_{m 2} \cdots & r_{m n}\end{array}\right]$

$\mathrm{R}$ adalah matriks yang telah dinormalisasi, dimana $m$ menyatakan alternatif, $n$ menyatakan kriteria dari $r i j$ adalah normalisasi pengukuran pilihan dari alternatif $k e-i$ dalam hubungannya dengan kriteria $k e-j$.

2. Pembobotan pada matriks yang telah dinormalisasi

Setelah dinormalisasi, setiap kolom dari matriks R dikalikan dengan bobot-bobot (wj) yang ditentukan oleh pembuat keputusan. Sehingga, weighted normalized matrix adalah V=RW yang ditulis sebagai :

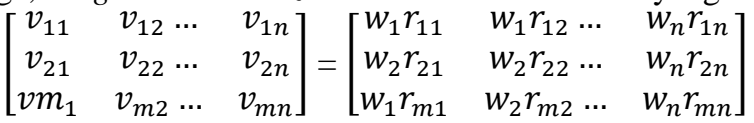

$$
\begin{aligned}
& \text { Dimana } W \text { adalah : } \\
& w=\left[\begin{array}{ccc}
w_{1} & 0 \ldots & 0 \\
0 & w_{2} \ldots & 0 \\
0 & 0 \ldots & w_{n}
\end{array}\right]
\end{aligned}
$$

3. Menentukan himpunan concordance dan discordance index

Untuk setiap pasang dari alternatif $\mathrm{k}$ dan $1(\mathrm{k}, \mathrm{l}=1,2,3, \ldots, \mathrm{m}$ dan $\mathrm{k} \neq 1)$ kumpulan $\mathrm{J}$ kriteria dibagi menjadi dua himpunan bagian, yaitu concordance dan discordance. Sebuah kriteria dalam suatu alternatif termasuk concordance jika:

$$
\mathrm{C}_{k l}=\left\{j, v_{k j} \geq v_{l j}\right\}, \text { untuk } \mathrm{j}=1,2,3, \ldots, \mathrm{n}
$$


Sebaliknya, komplementer dari himpunan bagian concordance adalah adalah himpunan discordance, yaitu bila:

4. Menghitung matriks concordance dan discordance

$$
\mathrm{Dkl}=\left\{\mathrm{j}, \mathrm{v} \_\mathrm{kj}<\mathrm{v} \_\mathrm{ij}\right\}, \text { untuk } \mathrm{j}=1,2,3, \ldots, \mathrm{n}
$$

a. Menghitung matriks concordance

Untuk menentukan nilai dari elemen-elemen pada matriks concordance adalah dengan menjumlahkan bobotbobot yang termasuk pada himpunan concordance, secara matematisnya adalah sebagai berikut:

b. Menghitung matriks discordance

$$
C_{k l} \sum_{j \in c k l} W j
$$

Untuk menentukan nilai dari elemen-elemen pada matriks discordance adalah dengan membagi maksimum selisih kriteria yang termasuk ke dalam himpunan bagian discordance dengan maksimum selisih nilai seluruh kriteria yang ada, secara matematisnya adalah sebagai berikut :

5. Menentukan matriks dominan concordance dan discordance

$$
d_{k l}=\frac{\max \left\{\left|v_{k j}-v_{l j}\right|\right\}_{j \in D k l}}{\max \left\{\left|v_{k l}-v_{l j}\right|\right\}_{\forall j}}
$$

a. Menghitung matriks dominan concordance dapat dibangun dengan bantuan nilai threshold, yaitu dengan membandingkan setiap nilai elemen matriks concordance dengan nilai threshold.

$$
\mathrm{Ckl} \geq \mathrm{c}
$$

Dengan nilai threshold (c) adalah :

$$
\underline{C}=\frac{\sum_{k=1}^{m} \sum_{l=1}^{m} c_{k l}}{m(m-1)}
$$

Sehingga elemen matriks F ditentukan sebagai berikut :

$$
f_{k l}=\left\{\begin{array}{l}
1, j i k a C_{k l} \geq \underline{C} \\
0, j i k a C_{k l}<\underline{C}
\end{array}\right.
$$

b. Menghitung matriks dominan discordance

Matriks G sebagai matriks dominan discordance dapat dibangun dengan bantuan nilai threshold d:

Dan elemen matriks $\mathrm{G}$ ditentukan sebagai berikut :

$$
\underline{d}=\frac{\sum_{k=1}^{m} \sum_{l=1}^{m} d_{k l}}{m(m-1)}
$$

$$
g_{k l}=\left\{\begin{array}{l}
1, \text { jika } d_{k l} \geq \underline{d} \\
0, \text { jika } d_{k l}<\underline{d}
\end{array}\right.
$$

6. Menentukan aggregate dominance matriks

Matriks E sebagai aggregate dominance matriks adalah matriks yang setiap elemennya merupakan perkalian anatara elemen matriks $\mathrm{F}$ dengan elemen matriks $\mathrm{G}$ yang bersesuaian, secara matematis dapat dinyatakan sebagai:

7. Eliminasi alternatif yang less favourable

$$
e_{k l}=f_{k l} \times g_{k l}
$$

Matriks E memberikan urutan pilihan dari setiap alternatif, yaitu bila ekl = 1 maka alternatif Ak merupakan alternatif yang lebih baik daripada A1. Sehingga, baris dalam matriks E yang memiliki jumlah ekl = 1 paling sedikit dapat dieliminasi. Dengan demikian, alternatif terbaik adalah alternatif yang mendominasi alternatif lainnya.

\section{PEMBAHASAN DAN HASIL}

\subsection{Analisis}

Dalam menentukan penerima bantuan PKH memerlukan alat bantu yang tepat yaitu komputer sebagai sarana yang dapat membantu pegawai kantor camat Borbor untuk mendapat informasi secara tepat dan akurat dengan suatu metode dan perhitungan sistematis yaitu metode Electre, metode ini dapat memberikan alternatif pilihan. Pada dasarnya metode Electre merupakan suatu metode untuk memecahkan suatu permasalahan dengan pengambilan keputusan berdasarkan perankingan dari alternatif-alternatif berdasarkan setiap kriteria. Berdasarkan metode ELECTRE akan dihasilkan suatu sistem yang mampu menentukan yang paling berhak menerima bantuan PKH yang diterapkan dalam suatu sistem pendukung keputusan, sehingga pembuat keputusan cukup menginput data-data yang diperlukan oleh sistem pendukung keputusan. Hasil yang diharapkan dapat membantu dalam pengambilan keputusan oleh pihak Kantor Camat Borbor untuk 
menentukan yang paling berhak menerima bantuan PKH. Pada penerapan metode ELECTRE dalam sistem pendukung keputusan untuk menentukan yang paling berhak menerima bantuan PKH di Kecamatan Borbor berdasarkan pekerjaan kepala keluarga, anak usia balita, anak usia 7-18 tahun, jenis dinding rumah, dan luas lantai rumah.

\subsubsection{Menentukan Kriteria}

Menentukan jumlah kriteria $(\mathrm{Cj})$ dari keputusan yang akan diambil untuk menentukan rating kecocokan setiap alternatif pada setiap kriteria.

Tabel .1 Tabel Kriteria

\begin{tabular}{|c|c|l|}
\hline No & Nama Kriteria & \multicolumn{1}{|c|}{ Keterangan } \\
\hline 1. & C1 & Pekerjaan Kepala Keluarga \\
\hline 2. & C2 & Anak Usia Balita \\
\hline 3. & C3 & Anak Usia 7-18 Tahun \\
\hline 4. & C4 & Jenis Dinding Rumah \\
\hline 5. & C5 & Luas Lantai Rumah \\
\hline
\end{tabular}

Berikut merupakan range dari setiapa kriteria.

Tabel .2 Range Pekerjaan Kepala Keluarga

\begin{tabular}{|c|c|}
\hline Kriteria & Range \\
\hline Buruh, Tukang kayu & 5 \\
\hline Petani & 4 \\
\hline Pegawai honorer & 3 \\
\hline Wirausaha & 2 \\
\hline PNS, dll & 1 \\
\hline
\end{tabular}

Tabel .3 Range Anak Usia Balita

\begin{tabular}{|c|c|}
\hline Kriteria & Range \\
\hline$>3$ & 5 \\
\hline 3 & 4 \\
\hline 2 & 3 \\
\hline 1 & 2 \\
\hline 0 & 1 \\
\hline
\end{tabular}

Tabel .4 Range Anak Usia 7-18 Tahun

\begin{tabular}{|c|c|}
\hline Kriteria & Range \\
\hline$>3$ & 5 \\
\hline 3 & 4 \\
\hline 2 & 3 \\
\hline 1 & 2 \\
\hline 0 & 1 \\
\hline
\end{tabular}

Tabel .5 Range Jenis Dinding Rumah

\begin{tabular}{|c|c|}
\hline Kriteria & Range \\
\hline Bambu & 3 \\
\hline Papan & 2 \\
\hline Tembok Batu, dll & 1 \\
\hline
\end{tabular}


Tabel .6 Range Luas Lantai Rumah

\subsubsection{Menentukan Alternatif}

\begin{tabular}{|c|c|}
\hline Kriteria & Range \\
\hline$<4$ & 5 \\
\hline 4 & 4 \\
\hline 5 & 3 \\
\hline 6 & 2 \\
\hline$>7$ & 1 \\
\hline
\end{tabular}

Alternatif merupakan objek atau solusi yang akan dihitung nilainya oleh sistem untuk menjadi calon penerima bantuan $\mathrm{PKH}$

Tabel .2 Tabel Alternatif

\begin{tabular}{|c|c|l|}
\hline No & Nama Alternatif & \multicolumn{1}{|c|}{ Keterangan } \\
\hline 1. & A1 & Jensika Sihombing \\
\hline 2. & A2 & Desy Uli Lubis \\
\hline 3. & A3 & Nova Sianipar \\
\hline 4. & A 4 & Lena Girsang \\
\hline 5. & A5 & Rosa Nainggolan \\
\hline
\end{tabular}

\subsubsection{Menentukan Bobot Penilaian}

Kriteria dan alternatif nantinya akan dinilai, kemudian data-data dicatat ke dalam form yang disediakan berdasarkan kriteria-kriteria tersebut. Nilai akan diproses oleh sistem untuk mendapatkan hasil akhir perhitungan. Adapun tabel penilaian dari metode ELECTRE adalah seperti tabel di bawah ini :

Tabel .3 Tabel Bobot Penilaian Perhitungan

\begin{tabular}{|c|c|}
\hline Nilai & Keterangan \\
\hline 5 & Sangat di Prioritaskan \\
\hline 4 & Di Prioritaskan \\
\hline 3 & Cukup di Prioritaskan \\
\hline 2 & Tidak di Prioritaskan \\
\hline 1 & Sangat Tidak Diprioritaskan \\
\hline
\end{tabular}

\subsubsection{Pembahasan Perhitungan ELECTRE}

Dalam pembahasan perhitungan ELECTRE ini, dapat diambil beberapa calon penerima yang memiliki 5 kriteria dengan nilai prefensi $(w)$ untuk setiap kriteria $(5,3,4,2,2)$. Perhitungan ELECTRE dalam sistem jika dicari secara manual. penyelesaiannya adalah sebagai berikut :

\subsubsection{Rating Kecocokan Alternatif Terhadap Setiap Kriteria}

Setiap nilai yang diberikan pada setiap alternatif di setiap kriteria merupakan nilai kecocokan dimana nilai terbesar adalah yang terbaik

Tabel .4 Kecocokan Alternatif Terhadap Setiap Kriteria

\begin{tabular}{|c|c|c|c|c|c|}
\hline \multirow{2}{*}{ Alternatif } & \multicolumn{5}{|c|}{ Kriteria } \\
\cline { 2 - 6 } & C1 & C2 & C3 & C4 & C5 \\
\hline A1 & 4 & 5 & 3 & 2 & 2 \\
\hline A2 & 5 & 2 & 4 & 2 & 2 \\
\hline A3 & 5 & 3 & 4 & 2 & 2 \\
\hline A4 & 4 & 3 & 5 & 2 & 2 \\
\hline A5 & 5 & 2 & 4 & 2 & 3 \\
\hline
\end{tabular}

1. $\mathrm{Ai}=\mathrm{A} 1, \mathrm{~A} 2, \mathrm{~A} 3, \mathrm{~A} 4, \mathrm{~A} 5$

2. $\mathrm{Cj}=$ pekerjaan kepala keluarga $(\mathrm{C} 1)$, anak usia balita $(\mathrm{C} 2)$, anak usia 7-18 tahun $(\mathrm{C} 3)$, jenis dinding rumah (C4), luas lantai rumah (C5)

3. Bobot prefensi untuk setiap kriteria $(\mathrm{C} 1, \mathrm{C} 2, \mathrm{C} 3, \mathrm{C} 4, \mathrm{C} 5)=5,3,4,2,2$

Keterangan : 
1. Nilai bobot prefensi untuk pekerjaan kepala keluarga bernilai 5

2. Nilai bobot prefensi untuk anak usia balita bernilai 3

3. Nilai bobot prefensi untuk anak usia 7-18 tahun bernilai 4

4. Nilai bobot prefensi untuk jenis dinding rumah bernilai 2

5. Nilai bobot prefensi untuk luas lantai rumah bernilai 2

Penyelesaian :

\subsubsection{Membuat Matriks Keputusan Ternormalisasi $R$}

$$
\mathrm{Rij}=\frac{x i j}{\sqrt{\sum_{i=1}^{m} X_{i j}^{2}}}
$$

a. Mencari nilai kriteria pekerjaan kepala keluarga (C1)

$$
\begin{aligned}
& \mathrm{X} 1=\sqrt{4^{2}+5^{2}+5^{2}+4^{2}+5^{2}}=10,3441 \\
& \mathrm{R} 11=\frac{x 11}{x 1}=\frac{4}{10,3441}=0,3867 \\
& \mathrm{R} 21=\frac{x 21}{x 1}=\frac{5}{10,3441}=0,4834 \\
& \mathrm{R} 41=\frac{x 41}{x 1}=\frac{4}{10,3441}=0,3867 \\
& \mathrm{R} 51=\frac{x 51}{x 1}=\frac{5}{10,3441}=0,4834 \\
& \mathrm{X} 2=\sqrt{5^{2}+2^{2}+3^{2}+3^{2}+2^{2}}=7,1414 \\
& \mathrm{R} 12=\frac{x 12}{x 2}=\frac{5}{7,1414}=0,7001 \\
& \mathrm{R} 22=\frac{x 22}{x 2}=\frac{2}{7,1414}=0,2801 \\
& \mathrm{R} 32=\frac{x 32}{x 2}=\frac{3}{7,1414}=0,4201 \\
& \mathrm{R} 42=\frac{x 42}{x 2}=\frac{3}{7,1441}=0,4201 \\
& \mathrm{R} 52=\frac{x 52}{x 2}=\frac{2}{7,1414}=0,2810
\end{aligned}
$$

c. Mencari nilai kriteria anak usia 7-18 tahun

$$
\begin{aligned}
& \mathrm{X} 3=\sqrt{3^{2}+4^{2}+4^{2}+5^{2}+4^{2}}=9,0554 \\
& \mathrm{R} 13=\frac{x 13}{x 3}=\frac{3}{9,0554}=0,3313 \\
& \mathrm{R} 23=\frac{x 23}{x 3}=\frac{4}{9,0554}=0,4417 \\
& \mathrm{R} 33=\frac{x 33}{x 3}=\frac{4}{9,0554}=0,4417 \\
& \mathrm{R} 43=\frac{x 43}{x 3}=\frac{5}{9,0554}=0,5522 \\
& \mathrm{R} 53=\frac{x 53}{x 3}=\frac{4}{9,0554}=0,4417
\end{aligned}
$$

d. Mencari nilai kriteria jenis dinding rumah

$$
\begin{aligned}
& \mathrm{X} 4=\sqrt{2^{2}+2^{2}+2^{2}+2^{2}+2^{2}}=4,4721 \\
& \mathrm{R} 14=\frac{x 14}{x 4}=\frac{2}{4,4721}=0,4472 \\
& \mathrm{R} 24=\frac{x 24}{x 4}=\frac{2}{4,4721}=0,4472 \\
& \mathrm{R} 34=\frac{x 34}{x 4}=\frac{2}{4,4721}=0,4472 \\
& \mathrm{R} 44=\frac{x 44}{x 4}=\frac{2}{4,4721}=0,4472 \\
& \mathrm{R} 54=\frac{x 54}{x 4}=\frac{2}{4,4721}=0,4472 \\
& \text { e. } \mathrm{M} \text { ncari nilai kriteria luas lantai rumah } \\
& \mathrm{X} 5=\sqrt{2^{2}}+2^{2}+2^{2}+2^{2}+3^{2}=5,000 \\
& \mathrm{R} 15=\frac{x 15}{x 5}=\frac{2}{5,000}=0,4000 \\
& \mathrm{R} 25=\frac{x 25}{x 5}=\frac{2}{5,000}=0,4000 \\
& \mathrm{R} 35=\frac{x 35}{x 5}=\frac{2}{5,000}=0,4000 \\
& \mathrm{R} 45=\frac{x 45}{x 5}=\frac{2}{5,000}=0,4000 \\
& \mathrm{R} 55=\frac{x 55}{x 5}=\frac{3}{5,000}=0,6000
\end{aligned}
$$

Maka dari perhitungan di atas menghasilkan matriks ternormalisasi R seperti terlihat di bawah ini : 


$\mathrm{R}=\left[\begin{array}{lllll}0,3867 & 0,7001 & 0,3313 & 0,4472 & 0,4000 \\ 0,4834 & 0,2801 & 0,4417 & 0,4472 & 0,4000 \\ 0,4834 & 0,4201 & 0,4417 & 0,4472 & 0,4000 \\ 0,3867 & 0,4201 & 0,5522 & 0,4472 & 0,4000 \\ 0,4834 & 0,2802 & 0,4417 & 0,4472 & 0,6000\end{array}\right]$

\subsubsection{Menghitung matriks $V$}

$\mathrm{V}=\mathrm{Wj} . \mathrm{Rij}$ (menghitung bobot ternormalisasi)

$\mathrm{W}=$ bobot prefensi $(5,3,4,2,2)$

$\mathrm{V}=\left[\begin{array}{lllll}5 * 0,3867 & 3 * 0,7001 & 4 * 0,3313 & 2 * 0,4472 & 2 * 0,4000 \\ 5 * 0,4834 & 3 * 0,2801 & 4 * 0,4417 & 2 * 0,4472 & 2 * 0,4000 \\ 5 * 0,4834 & 3 * 0,4201 & 4 * 0,4417 & 2 * 0,4472 & 2 * 0,4000 \\ 5 * 0,3867 & 3 * 0,4201 & 4 * 0,5522 & 2 * 0,4472 & 2 * 0,4000 \\ 5 * 0,4834 & 3 * 0,2802 & 4 * 0,4471 & 2 * 0,4472 & 3 * 0,6000\end{array}\right]$

Maka akan menghasilkan matriks $\mathrm{V}$ seperti dibawah ini :

$\mathrm{V}=\left[\begin{array}{lllll}1,9335 & 2,1003 & 1,3252 & 0,8944 & 0,8000 \\ 2,4168 & 0,8403 & 1,7669 & 0,8944 & 0,8000 \\ 2,4168 & 1,2603 & 1,7669 & 0,8944 & 0,8000 \\ 1,9335 & 1,2603 & 2,2086 & 0,8944 & 0,8000 \\ 2,4168 & 0,8403 & 1,7669 & 0,8944 & 1,2000\end{array}\right]$

\subsubsection{Menentukan Himpunan Concordance dan Discordance}

a. Concordance

$\mathrm{C}_{k l}=\left\{j, v_{k j} \geq v_{l j}\right\}$, untuk $\mathrm{j}=1,2,3, \ldots, \mathrm{n}$

Matriks concordance dicari dengan membandingkan tiap-tiap baris alternatif pada kriteria-kriteria yang ada di bawah ini :

$$
\begin{aligned}
\mathrm{C} 12 & =\left\{j, v_{1 j} \geq v_{2 j}\right\} \text { untuk } j=1,2, \ldots \ldots, 5 \\
& =\{2,4,5\} \\
\mathrm{C} 13 & =\left\{j, v_{1 j} \geq v_{3 j}\right\} \text { untuk } j=1,2, \ldots \ldots, 5 \\
& =\{2,4,5\}
\end{aligned}
$$

$\mathrm{C} 14=\{1,2,4,5\}$

$\mathrm{C} 15=\{2,4\}$

$\mathrm{C} 21=\{1,3,4,5\}$

$\mathrm{C} 23=\{1,3,4,5\}$

$\mathrm{C} 24=\{1,4,5\}$

$\mathrm{C} 25=\{1,2,3,4\}$

$\mathrm{C} 31=\{1,3,4,5\}$

$\mathrm{C} 32=\{1,2,3,4,5\}$

$\mathrm{C} 34=\{1,2,4,5\}$

$\mathrm{C} 35=\{1,2,3,4\}$

$\mathrm{C} 41=\{1,3,4,5\}$

$\mathrm{C} 42=\{2,3,4,5\}$

$\mathrm{C} 43=\{2,3,4,5\}$

$\mathrm{C} 45=\{2,3,4\}$

$\mathrm{C} 51=\{1,3,4,5\}$

$\mathrm{C} 52=\{1,2,3,4,5\}$

$\mathrm{C} 53=\{1,3,4,5\}$

$\mathrm{C} 54=\{1,4,5\}$

b. Discordance

Sebuah kriteria dalam suatu alternatif termasuk discordance jika :

$$
\begin{aligned}
\mathrm{D}_{k l} & =\left\{j, v_{k j}<v_{i j}\right\}, \text { untuk } \mathrm{j}=1,2,3, \ldots, \mathrm{n} \\
\mathrm{D} 12 & =\left\{j, v_{1 j}<v_{2 j}\right\} \text { untuk } j=1,2, \ldots \ldots, 5 \\
& =\{1,3\} \\
\mathrm{D} 13 & =\left\{j, v_{1 j}<v_{3 j}\right\} \text { untuk } j=1,2, \ldots \ldots, 5 \\
& =\{1,3\} \\
\mathrm{D} 14 & =\{3\} \\
\mathrm{D} 15 & =\{1,3,5\} \\
\mathrm{D} 21 & =\{2\} \\
\mathrm{D} 23 & =\{2\}
\end{aligned}
$$




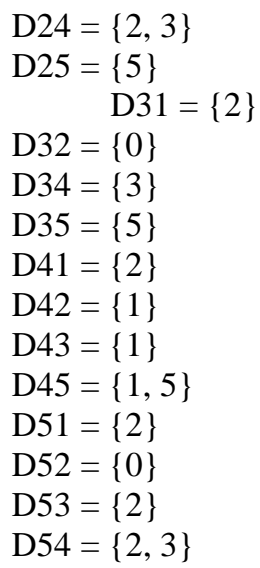

3.1.8 Menghitung Matriks Concordance dan Discordance

a. Menghitung matriks concordance

W : bobot prefensi $(5,3,4,2,2)$

$\mathrm{C} 12=\mathrm{w} 2+\mathrm{w} 4+\mathrm{w} 5$

$$
=3+2+2=7
$$

$\mathrm{C} 13=\mathrm{w} 2+\mathrm{w} 4+\mathrm{w} 5$

$$
=3+2+2=7
$$

$\mathrm{C} 14=\mathrm{w} 1+\mathrm{w} 2+\mathrm{w} 4+\mathrm{w} 5$

$$
=5+3+2+2=12
$$

$\mathrm{C} 15=\mathrm{w} 2+\mathrm{w} 4+\mathrm{w} 5$

$$
=3+2=5
$$

$\mathrm{C} 21=\mathrm{w} 1+\mathrm{w} 3+\mathrm{w} 4+\mathrm{w} 5$

$$
=5+4+2+2=13
$$

$\mathrm{C} 23=\mathrm{w} 1+\mathrm{w} 3+\mathrm{w} 4+\mathrm{w} 5$

$$
=5+4+2+2=13
$$

$\mathrm{C} 24=\mathrm{w} 1+\mathrm{w} 4+\mathrm{w} 5$

$$
=5+2+2=9
$$

$\mathrm{C} 25=\mathrm{w} 1+\mathrm{w} 2+\mathrm{w} 3+\mathrm{w} 4$

$$
=5+3+4+2=14
$$

$\mathrm{C} 31=\mathrm{w} 1+\mathrm{w} 3+\mathrm{w} 4+\mathrm{w} 5$

$$
=5+4+2+2=13
$$

$\mathrm{C} 32=\mathrm{w} 1+\mathrm{w} 2+\mathrm{w} 3+\mathrm{w} 4+\mathrm{w} 5$

$$
=5+3+4+2+2=16
$$

$\mathrm{C} 34=\mathrm{w} 1+\mathrm{w} 2+\mathrm{w} 4+\mathrm{w} 5$

$$
=5+3+2+2=12
$$

$\mathrm{C} 35=\mathrm{w} 1+\mathrm{w} 2+\mathrm{w} 3+\mathrm{w} 4$

$$
=5+3+4+2=14
$$

$\mathrm{C} 41=\mathrm{w} 1+\mathrm{w} 3+\mathrm{w} 4+\mathrm{w} 5$

$$
=5+4+2+2=13
$$

$\mathrm{C} 42=\mathrm{w} 2+\mathrm{w} 3+\mathrm{w} 4+\mathrm{w} 5$

$$
=3+4+2+2=11
$$

$\mathrm{C} 43=\mathrm{w} 2+\mathrm{w} 3+\mathrm{w} 4+\mathrm{w} 5$

$$
=3+4+2+2=11
$$

$\mathrm{C} 45=\mathrm{w} 2+\mathrm{w} 3+\mathrm{w} 4$

$$
=3+4+2=9
$$

$\mathrm{C} 51=\mathrm{w} 1+\mathrm{w} 3+\mathrm{w} 4+\mathrm{w} 5$

$$
=5+4+2+2=13
$$

$\mathrm{C} 52=\mathrm{w} 1+\mathrm{w} 2+\mathrm{w} 3+\mathrm{w} 4+\mathrm{w} 5$

$$
=5+3+4+2+2=16
$$

$\mathrm{C} 53=\mathrm{w} 1+\mathrm{w} 3+\mathrm{w} 4+\mathrm{w} 5$

$$
=5+4+2+2=13
$$

$\mathrm{C} 54=\mathrm{w} 1+\mathrm{w} 4+\mathrm{w} 5$

$$
=5+2+2=9
$$


Jadi, matriks concordance adalah :

$$
\mathrm{C}=\left[\begin{array}{ccccc}
- & 7 & 7 & 12 & 5 \\
13 & - & 13 & 9 & 14 \\
13 & 16 & - & 12 & 14 \\
13 & 11 & 11 & - & 9 \\
13 & 16 & 13 & 9 & -
\end{array}\right]
$$

b. Menghitung matriks discordance

$$
\begin{aligned}
& \mathrm{D} 12=\frac{\max \left\{\left|v_{1 j}-v_{2 j}\right|\right\} \in D 12}{\max \left\{\left|v_{1 j}-v_{2 j}\right|\right\} \forall j} \\
& d_{k l}=\frac{\max \left\{\left|v_{k j}-v_{l j}\right|\right\}_{j \in D k l}}{\max \left\{\left|v_{k l}-v_{l j}\right|\right\}_{\forall j}} \\
& \max \{|1,9335-2,4168 ;| 1,3252-1,7669 \mid\} \\
& =\overline{\max \{|1,9335-2,4168| ;|2,1004-1,1202| ;|1,3252-1,7669| ;|0,8944-0,8944| ;|0,8000-0,8000|\}} \\
& =-0,3837 \\
& \mathrm{D} 13=\frac{\max \left\{\left|v_{1 j}-v_{3 j}\right|\right\} \in D 13}{\max \left\{\left|v_{1 j}-v_{3 j}\right|\right\} \forall j} \\
& =\frac{\max \{|1,9335-2,4168 ;| 1,3252-1,7669 \mid\}}{\max } \\
& =\overline{\max \{|1,9335-2,4168| ;|2,1004-1,6803| ;|1,3252-1,7669| ;|0,8944-0,8944| ;|0,8000-0,8000|\}} \\
& =0,5755 \\
& \mathrm{D} 14=\frac{\max \left\{\left|v_{1 j}-v_{4 j}\right|\right\} \in D 14}{\max \left\{\left|v_{1 j}-v_{4 j}\right|\right\} \forall j} \\
& \max \{|1,3252-2,2086|\} \\
& =\overline{\max \{|1,9335-1,9335| ;|2,1004-1,6803| ;|1,3252-2,2086| ;|0,8944-0,8944| ;|0,8000-0,8000|\}} \\
& =1
\end{aligned}
$$

D15 $=-0,3837$

D21 = 1

D23 $=1$

D24 $=0,9141$

D25 $=1$

\begin{tabular}{|c|c|c|c|c|c|}
\hline & \multirow{2}{*}{$\begin{array}{c}- \\
1\end{array}$} & 0,3837 & 0,5755 & 1 & 0,3837 \\
\hline & & - & 1 & 0,9141 & 11 \\
\hline & 1 & 0,0000 & - & 1 & 0,9523 \\
\hline & 0,9506 & 1 & 1 & - & 1 \\
\hline & 1 & 0,0000 & 1 & 0,9141 & - \\
\hline
\end{tabular}

$\mathrm{D} 31=1$

D32 $=0,0000$

D34 $=-0,9141$

D35 $=0,9523$

D41 $=0,9506$

D42 $=1$

D43 = 1

D45 = 1

D51 $=1$

D52 $=0,0000$

$\mathrm{D} 53=1$

D54 $=0,9141$

Jadi matriks discordance adalah :

\subsubsection{Menentukan Matriks Dominan Concordance dan Discordance}

a. Menghitung matriks dominan concordance

Nilai threshold (c) adalah :

$$
\begin{aligned}
\underline{C}=\frac{\sum_{k=1}^{m} \sum_{l=1}^{m} c_{k l}}{m(m-1)} & \\
\underline{\mathrm{C}} & =\frac{7+7+12+5+13+13+9+5+13+16+12+14+13+11+11+9+13+16+13+9}{5(5-1)} \\
& =\frac{221}{20}=11,05
\end{aligned}
$$

Elemen matriks $\mathrm{F}$ ditentukan sebagai berikut :

$F k l=1$, jika $C k l \geq C$

$F k l=0$, jika $C k l<\underline{C}$

Sehingga matriks dominan concordance adalah : 
$\mathrm{F}=\left[\begin{array}{ccccc}- & 0 & 0 & 1 & 0 \\ 1 & - & 1 & 0 & 1 \\ 1 & 1 & - & 1 & 1 \\ 1 & 0 & 0 & - & 0 \\ 1 & 1 & 1 & 0 & -\end{array}\right]$

b. Menghitung matriks dominan discordance

Nilai threshold (d) adalah :

$$
\begin{aligned}
& \underline{d}=\frac{\sum_{k=1}^{m} \sum_{l=1}^{m} d_{k l}}{m(m-1)} \\
& 0,3837+0,5755+1+0,3837+1 \\
& +1+1+0,9141+1+1 \\
& +0+0,9141+0,9523+0,9506+1 \\
& \underline{\mathrm{D}}=\frac{\begin{array}{c}
+1+1+0 \\
+1+0,9141
\end{array}}{5(5-1)} \\
& =\frac{16,9387}{20} \\
& =0,7994
\end{aligned}
$$

Elemen matriks $\mathrm{G}$ ditentukan sebagai berikut :

$$
\begin{aligned}
& G k l=1, \text { jika } d k l \geq \underline{\mathrm{d}} \\
& G k l=0, \text { jika } d k l<\underline{\mathrm{d}} \\
& \mathrm{G}=\left[\begin{array}{cccccc}
- & 0 & 0 & 1 & 0 \\
1 & - & 1 & 1 & 1 \\
1 & 0 & - & 1 & 1 \\
1 & 1 & 1 & - & 1 \\
1 & 0 & 1 & 1 & -
\end{array}\right]
\end{aligned}
$$

\subsubsection{Menentukan Aggregate Dominance Matriks}

Rumus umum untuk aggregate dominan matriks adalah :

$$
\begin{aligned}
& \mathrm{E} 12=0 * 0=0 \\
& \mathrm{E} 13=0 * 0=0 \\
& \mathrm{E} 14=1 * 1=1 \\
& \mathrm{E} 15=1 * 0=0 \\
& \mathrm{E} 21=1 * 1=1 \\
& \mathrm{E} 23=1 * 1=1 \\
& \mathrm{E} 24=0 * 1=0 \\
& \mathrm{E} 25=1 * 1=1 \\
& \mathrm{E} 31=1 * 1=1 \\
& \mathrm{E} 32=1 * 0=0 \\
& \mathrm{E} 34=1 * 1=1 \\
& \mathrm{E} 35=1 * 1=1 \\
& \mathrm{E} 41=1 * 1=1 \\
& \mathrm{E} 42=0 * 1=0 \\
& \mathrm{E} 43=0 * 1=0 \\
& \mathrm{E} 45=0 * 1=0 \\
& \mathrm{E} 51=1 * 1=1 \\
& \mathrm{E} 52=1 * 0=0 \\
& \mathrm{E} 52=1 * 1=1 \\
& \mathrm{E} 54=1 * 1=1
\end{aligned}
$$

\subsubsection{Eliminasi Alternatif yang Less Favourable}

Matriks E memberikan urutan pilihan dari setiap alternatif, yaitu bila ekl $>1$ maka alternatif $A k$ merupakan pilihan yang lebih baik daripada $A l$. Sehingga baris dalam matriks $E$ yang memiliki jumlah $e k l$ $=1$ paling sedikit dapat dieliminasi. Dengan demikian jika hasil dari matriks aggregate (ekl) $\leq 1$ maka tidak layak dan $\geq 2$ maka layak

Tabel .5 Agregate Dominance matriks E

\begin{tabular}{|c|c|c|c|c|c|c|c|c|}
\hline \multirow{2}{*}{ Alternatif } & \multicolumn{4}{|c|}{ E } & Hasil & Keterangan \\
\hline A1 & Jensika Sihombing & - & 0 & 0 & 1 & 0 & 1 & Tidak layak \\
\hline A2 & Desy Uli Lubis & 1 & - & 1 & 0 & 1 & 3 & Layak \\
\hline A3 & Lena Girsang & 1 & 0 & - & 1 & 1 & 3 & Layak \\
\hline
\end{tabular}




\begin{tabular}{|c|c|c|c|c|c|c|c|c|}
\hline A4 & Nova Sianipar & 1 & 0 & 0 & - & 0 & 1 & Tidak Layak \\
\hline A5 & Rosa Nainggolan & 0 & 0 & 1 & 1 & - & 2 & Layak \\
\hline
\end{tabular}

Berikut ini merupakan hasil tampilan Sistem Pendukung Keputusan Pemberian Bantuan Program Keluarga Harapan (PKH) dengan Metode Metode ELimination Et Choix Traduisant la Realite (ELECTRE) Studi Kasus Kecamatan Borbor. Pada Form data penduduk pegawai bisa melakukan penginputan data penduduk berupa tambah, simpan, hapus, batal, keluar yang terdapat pada database

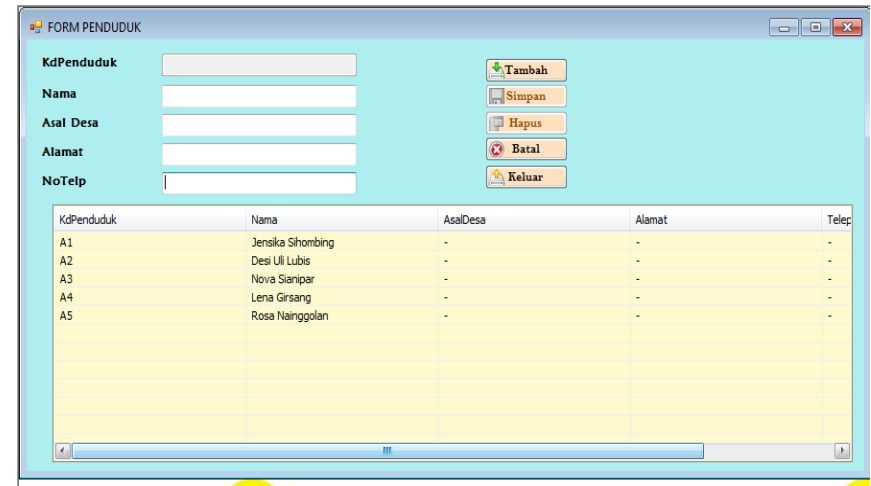

Gambar.3 Form Data Penduduk

Pada Form kriteria pegawai bisa melakukan pengolahan data kriteria berupa tambah, simpan, hapus, batal, keluar yang terdapat di database

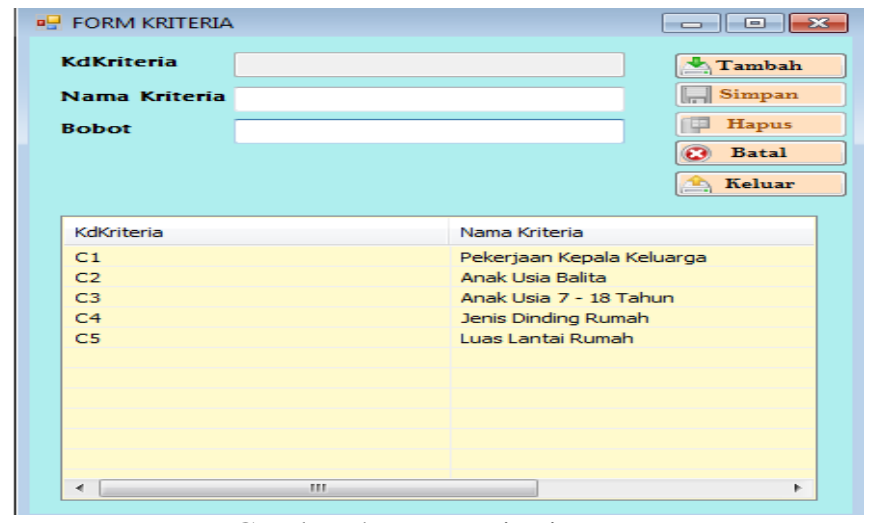

Gambar.4 Form Kriteria

Pada form penilaian merupakan form yang akan digunakan untuk proses pemberian nilai dari masing-masing kriteria dari masing-masing calon penerima bantuan. Dimana pegawai mengisi nilai dari masing-masing kriteria

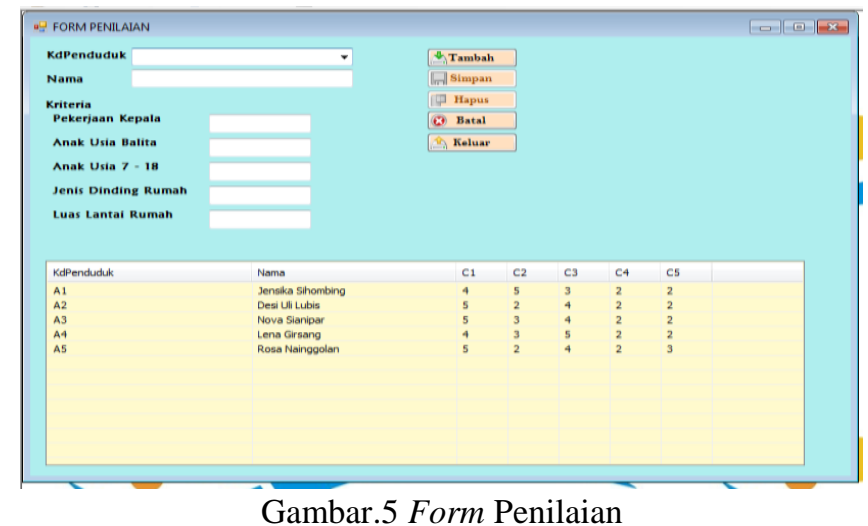

Pada form subkriteria merupakan form yang akan dibuat untuk pemberian range dari masing-masing alternatif 


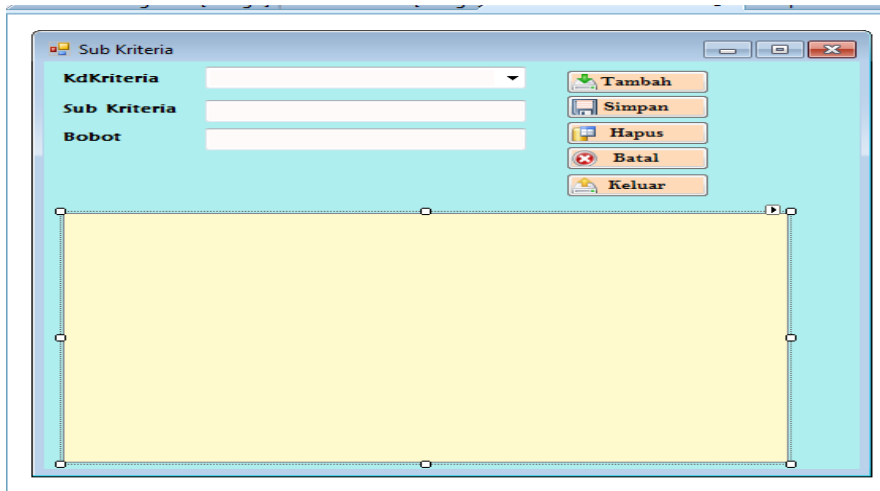

Gambar.5 Form Subkriteria

Pada form ini merupakan proses dimana perhitungan dilakukan dengan metode ELECTRE, hal ini pertama yang dilakukan setelah penentuan nilai masing-masing calon pada kriteria yang tersedia, selanjutnya ketika pegawai mengklik perhitungan di menu utama maka nilai matriks keputusan ternormalisasi, nilai Matriks V, matriks concordance dan discordance, matriks dominan concordane dan discordance, matriks aggregate dan hasilnya akan tampil.

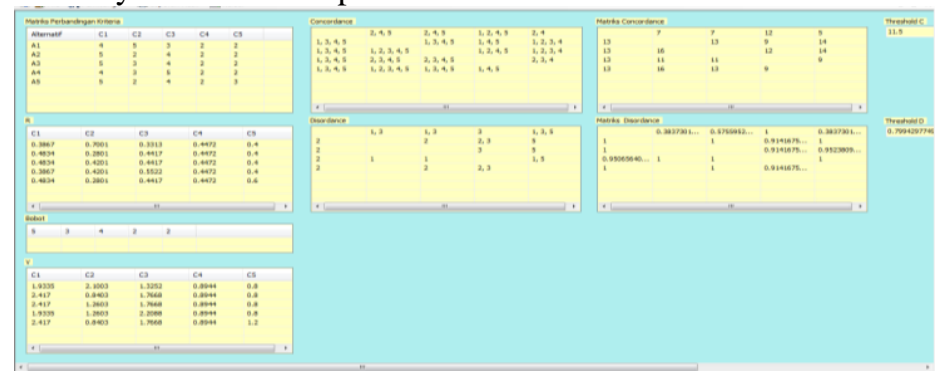

Gambar.6 Form Perhitungan ELECTRE

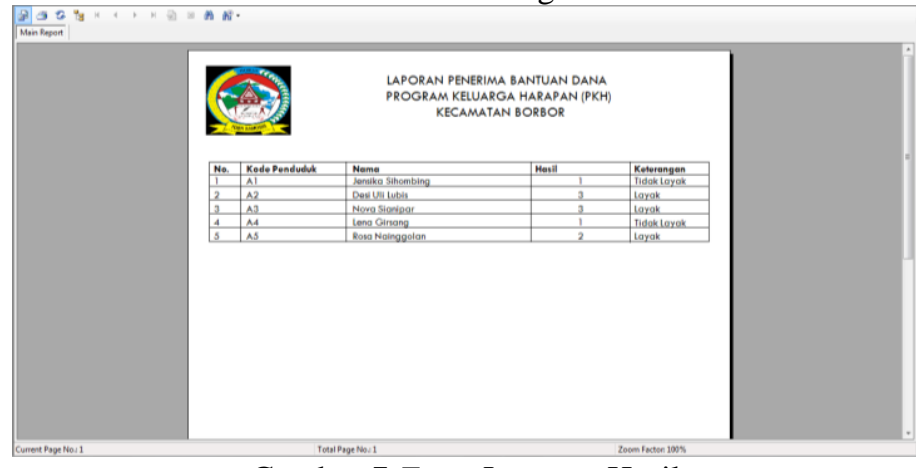

Gambar.7 Form Laporan Hasil

\section{KESIMPULAN}

Perancangan aplikasi sistem pendukung keputusan dalam menentukan penerima bantuan PKH menggunakan aplikasi sistem pendukung keputusan dengan metode Electre yang telah diselesaikan dan diambil beberapa kesimpulan diantaranya adalah :

1. Adapun cara untuk menetukan penerima bantuan PKH pada Kecamatan Borbor yaitu terlebih dahulu mengumpulkan data keluarga yang berhak menerima bantuan tersebut dan akan dikumpulkan di kantor camat

2. Borbor, kemudian melakukan perhitungan dengan Electre serta merancang sebuah program apliksi. Sehingga dengan perhitungan Electre dan mengimplementasikan sistem pendukung keputusan kedalam perancangan aplikasi. Sehingga pegawai dapat dengan mudah menampilkan hasil keputusan penerima bantuan PKH.

3. Adapun penerapan metode Electre dengan mengimplementasikan sistem pendukung keputusan untuk penerima bantuan PKH dengan cara menginput bobot dari setiap penduduk dan dilakukan proses perhitungan dengan metode Electre sehingga tampil yang berhak menerima pinjaman. 
4. Adapun perancangan aplikasi mengguanakan bahasa pemrograman dilakukan dengan cara menganalisa permasalahan dan kebutuhan bagi pengguna aplikasi sehingga aplikasi dapat sesuai dengan keinginan dari pengguna.

\section{REFERENSI}

[1] Kusrini, 2007, Konsep dan Aplikasi Sistem Pendukung Keputusan. Yogyakarta : $\quad$ Penerbit Andi.

[2]Wikipedia.ELECTREpadahttps://translate.google.co.id/translate?hl=id\&sl=en\&u=https://en.wikipwdia.or g/wiki/ELECTRE\&prev=search..

[3] Putra, Abner Adi., Andreswari, Desi., \& Susilo,Boko. 2015. Sistem Pendukung Keputusan Untuk Penerima Bantuan Pinjaman Samisake dengan Menggunakan Metode Electre (Studi kasus : LKM Kelurahan Lingkar Timur Kota Bengkulu). Jurnal Rekursif , 3(1).1-11.

[4] Akshareari, Syeril. 2013. Sistem Pendukung Keputusan Pemilihan Produksi Sepatu dengan Metode Elimination Et Choix Traduisant la Realie (Electre). Bandung : Universitas Pendidikan Indonesia. 